\title{
The Women's Construction Collective: Building for the future
}

Ruth McLeod

Follow this and additional works at: https://knowledgecommons.popcouncil.org/departments_sbsr-pgy

Part of the Family, Life Course, and Society Commons, Gender and Sexuality Commons, International Public Health Commons, Regional Economics Commons, and the Work, Economy and Organizations Commons How does access to this work benefit you? Let us know!

\section{Recommended Citation} McLeod, Ruth. 1986. "The Women's Construction Collective: Building for the future," SEEDS no. 9. New York: Population Council. 

SEEDS is a pamphlet series developed to meet requests from all over the world for information about innovative and practical program ideas developed by and for low income women. The pamphlets are designed as a means to share information and spark new projects based on the positive experiences of women who are working to help themselves and other women improve their economic status. The projects described in this and other issues of SEEDS have been selected because they provide women with a cash income, involve women in decision-making as well as earning, are based on sound economic criteria, and are working successfully to overcome obstacles commonly encountered. The reports are not meant to be prescriptive, since every development effort will face somewhat different problems and resources. Rather, they have been written to describe the history of an idea and its implementation in the hope that the lessons learned can be useful in a variety of settings. They are also being written to bring to the attention of those in decision-making positions the fact that income generating projects for and by women are viable and have important roles to play in development.

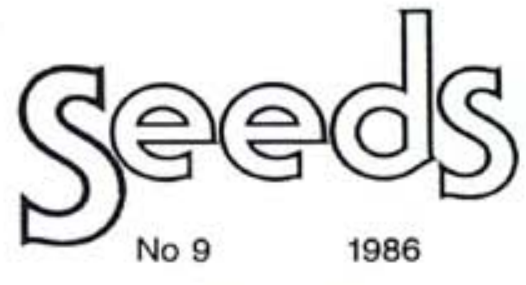

ISSN 073-6833
Administrative support and project direction for SEEDS is provided by The Population Council. Editorial policy is set by the SEEDS Steering Committee: Judith Bruce (The Population Council), Anne Kubisch (The Ford Foundation), Katharine McKee (The Ford Foundation). Jill Sheffield (The Camegie Corporation), William O. Sweeney (Communications Consultant) and Ann Leonard (Editor).

Publication of SEEDS is made possible by support of the Carnegie Corporation, the Ford Foundation, Oxfam America and the Population Council.

Statements made and views expressed in this publication are solely the responsibility of the author and not of any organization providing support for SEEDS. 


\title{
The Women's \\ Construction Collective: Building for the Future
}

\author{
Story by Ruth Mcleod
}

\section{Introduction}

The Caribbean island of Jamaica has a population of roughly two million people, over half of whom live in urban areas, the largest being the capital city of Kingston. The island's sophistication is clearly demonstrated by the high-rise buildings that comprise Kingston's financial center and the luxury hotels that dot the island's North Coast. However other tell-tale signs of rapid urban development are also highly visible: squatter settlements and urban ghettos characterized by high unemployment, political partisanship and a low standard of living. In these densely populated areas a complexity of social, economic and political problems confront development planners, particularly those concerned with improving the status of women.

Given that at least one-third of the island's households, and one half of those in urban areas, are headed by women, and given that women's unemployment rates are over twice those for men, it is not surprising that the position of women within Jamaican society and their role in the development process attracted considerable attention during the International Decade of Women (1975-1985).

This edition of SEEDS focuses on a project developed to integrate low-income women into Jamaica's construction industry. In two years, 34 women have passed through the project's basic training and skills upgrading courses. More than 90 percent of these women have been employed, the majority as masons and carpenters. The story of how this field was identified as a potential source of income for women, and how the project developed and evolved in response to changing circumstances, presents many useful lessons. These should be of particular interest to those seeking to identify employment areas where women's participation is feasible and in helping them prepare women for entry into nontraditional skill areas. 


\section{The Urban Working Groups}

In July 1981, the Population Council initiated a program entitled, "Women, Low Income Households and Urban Services in Latin America and the Caribbean." Its goal was to bring low income women's concerns into the existing urban planning and service delivery process through the creation of local working groups in three metropolitan areas: Kingston, Jamaica; Lima, Peru; and Mexico City, Mexico. The working groups were made up of urban planners, researchers and statisticians, development practitioners and social scientists. This encouraged linkages to grow between government bureaucracies, academia and community development organizations. Through the working groups, information about the urban poor from a variety of perspectives was brought together and realistic priorities for action were identified.

The Population Council, under a cooperative agreement with the U.S. Agency for International Development's (USAID) Office of Urban Development and Housing*, provided each working group with a modest fund which could be used to support low budget projects such as documentation of ongoing action projects. experimentation with new service approaches, reanalysis of existing data and generation of new, primarily qualitative, information. The information and policy advice generated by the working groups were then disseminated locally by the groups themselves, internationally through the publication of working papers, and through meetings and seminars coordinated by the Population Council.

\section{Identifying the Need}

In May 1983 the Jamaica Working Group, made up of approximately a dozen planners, researchers and community development specialists, approved a proposal

\footnotetext{
- The work continues into a second phase (1985-1987) with support from the Women in Development Office of USAID. The Kingston Women's Construction Collective is one of the successful projects undertaken by the Kingston Working Group as a part of this overall program.
}

for an experimental project to train and place unemployed women in jobs at the trade level of the Jamaican building and construction industry. Why women in construction? Three factors were behind the Group's decision to pursue a project to train and integrate women into the construction industry:

(1) In mid-1982 the building industry was booming. According to the Planning Institute of Jamaica, the industry grew by 14.8 percent in $1981-82$ and by mid-1983 it was contributing 6.1 percent to the island's GDP while employing 32,000 people. The president of the Masterbuilders, an organization representing construction contractors, had predicted that 5,000 new skilled workers would be required annually for the next three years. However, only 800 of those 32,000 currently employed were women. Of these, only 100 women were ranked as professionals, 600 were clerical or service workers and 100 were unskilled manual workers. Women also were unrepresented in official Government statistics as trade workers in the industry.

(2) In effect, women had recently been excluded from entry into the Government's building and construction training program at the trade level due to implementation of a new training policy. Before 1983, over 100 industrial training centers were in operation throughout the island, offering daytime classes on a coeducational basis. An estimated 1000 women were trained in building skills between 1976 and 1980, though few had found jobs in the industry. In 1983, the Government shifted to a policy of utilizing a smaller number of larger training facilities that offered residential training for men only. While theoretically open to women on a day student basis, as of December 1985, not a single woman had been trained in building skills under this new system.

(3)There was particular concern that the high unemployment rate for young women would undermine the National Family Planning Board's attempt to reduce teenage fertility through the pro- 


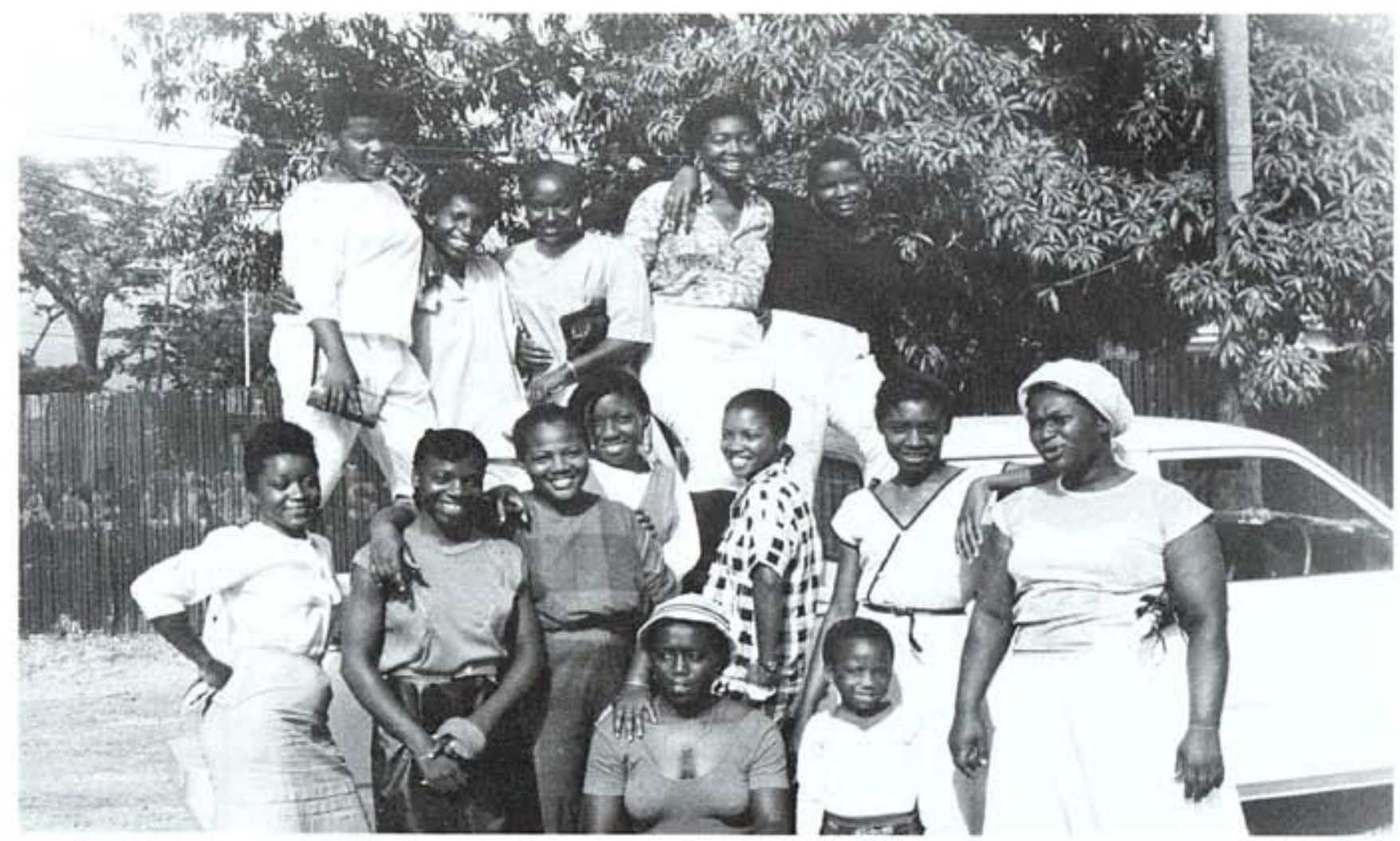

vision of free family planning services. A positive correlation had been observed between female unemployment and fertility, particularly in the ghetto areas where the role of "baby mother" (in Jamaica mothers are typically called "baby mothers" while fathers are referred to as "baby fathers") was frequently the only source of status available to young women.

The Working Group found the proposed project of particular interest because it would address these problems at both the industry and community levels and might offer a way to strengthen linkages between training and job placement for women. At the same time it would offer an opportunity to document the role of women within a nontraditional skill area. The latter was of high priority since there were no accounts of the women who had received construction skills training earlier or of the results of their job seeking efforts. These women thus remained invisible within the statistics and could not serve as a positive example for the construction industry or provide role models for other women. In the absence of such documentation, policy makers developing training programs tended to as- sume that women either were not interested in the construction area and/or were unable to find work in this sector.

\section{Laying the Groundwork}

The project began with the formation of a collective which would be the vehicle through which a training program, tailored to the specific needs of young, unemployed, low-income women could be made available. Not only would this training program provide women with skills, it would also help them learn about the realities of the workplace, including men's reactions, and develop strategies to overcome their fears about the practical obstacles involved in working in a male-dominated field.

Initial plans called for ten unemployed women from Western Kingston to be selected, put through an intensive training program, placed in jobs and monitored so that their experiences, over a 15-month period, could be closely documented both photographically and in writing. The documentation would serve to strengthen the case for opening the Government Skills Training Program to women. 
The project was proposed and has been coordinated by Ruth Mcleod, who was originally a human resource development consultant to the Incorporated Masterbuilders Association of Jamaica (IMBA), an organization that represents nearly 80 percent of the island's building contractors. Her role at the IMBA was to advise the Government on building skills training curriculum. She later became managing director of the Construction Resources and Development Center (CRDC), an independent nonprofit research and development organization made up of representatives from seven professional and trade associations, including architects, engineers, surveyers and trade unions.

A number of problems had to be addressed from the outset. One concerned the 66 occupational groups recognized in the Jamaican construction industry, many of them with three grade levels. Which would provide the best opportunities for job placement? These complications were exacerbated by traditional hiring practices. Subcontracting is a major feature of the Jamaican construction industry, with between 70 and 100 percent of all trade work on each site being carried out by subcontractors on a task basis. The vast majority of subcontractors work through informal trade gangs, the composition of which may change as often as the jobs. Most subcon- tractors have no known addresses, let alone telephones or secretaries. Entry into these trade gangs occurs through access to a male network of friends, relatives and workers met on previous jobs. Clearly this was not going to be an easy network to break into-particularly through formal, let alone female channels.

The balance of building work, however, is carried out on a direct hire, day-rate basis. In this mode, the main contractor normally hires site supervisors, timekeepers, equipment and plant operators, security guards, trade helpers and casual laborers. Trade helpers are often selected from amongst the laborers and may be assigned to work with specific trade subcontractors as construction progresses. The planners felt that if women could find employment as trade helpers, this would provide them with access to the subcontractors' network which, in turn, would provide them with onthe-job training opportunities and the chance to upgrade their building skills while earning an income.

Another complication was presented by the extensive influence of territorial political rivalries in the Jamaican construction industry. If a site is located in an area associated with a particular political party, the followers of that party automatically expect exclusive job privileges. These expectations are encouraged by official or semi-of-

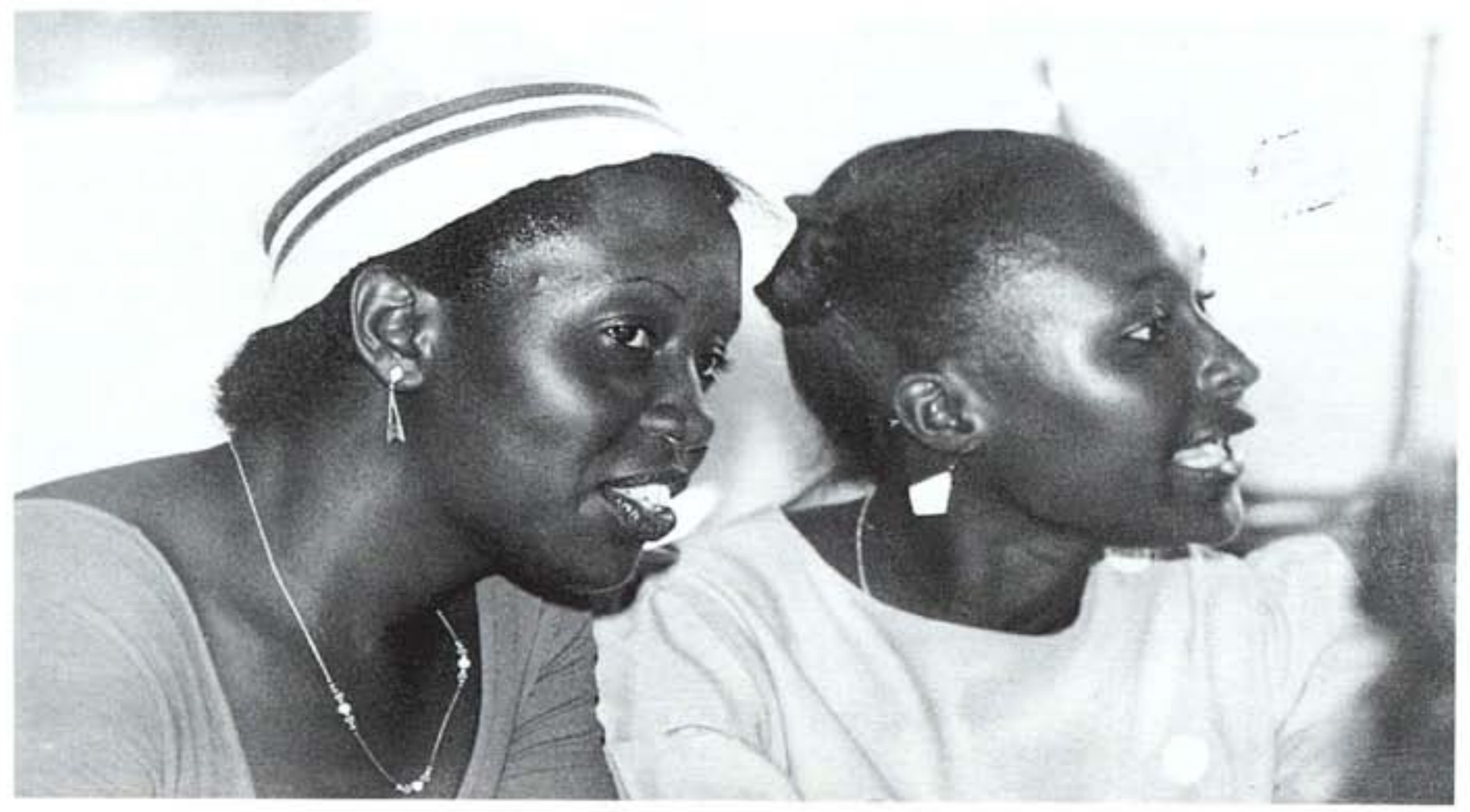


ficial representatives and those affiliated with other political parties enter at their own risk, unless they possess a scarce skill or a strong tie to the main contractor. Early on the Collective realized that it might have to confront the violence associated with this political territoriality in developing its program.

An additional problem was accurately anticipating the funds required to operate the project. The initial budget provided by the Working Group was U.S. $\$ 8,000$ over a 15 -month period. This amount would need to cover facilities and instructors, materials and transportation, and the job placement process, which would require time for research and establishment of appropriate contacts. Any major deviations in planning could require additional fundraising.

The first step in developing the training program was locating a suitable training base. This task was undertaken by the Project Coordinator, given her experience in the field and her knowledge of agencies able to provide such training. The CRDC often develops experimental training programs for adult construction workers, frequently in cooperation with the Vocational Training Development Institute (VTDI). VTDI is an agency responsible for training vocational instructors for Jamaica and other Caribbean islands. It also provides short-term courses to upgrade skills in a wide variety of industrial areas. The project benefited from working with both CRDC and VTDI in developing its training program.

The second step was identifying potential trainees. One member of the Working Group, the Community Liaison Officer for the Western Kingston area, agreed to select the participants. All were to be chosen from the Tivoli Gardens section of Western Kingston, a community developed as part of an upgrading scheme during the 1960 s when the Jamaican Labour Party (JLP) was in power. It consists of 1,000 living units, mostly four-storied apartment blocks and terraced units. This community strongly supports the current Prime Minister. It is characterized by high rates of female unemployment and teenage pregnancy and a large population of young women with dependent children. Women were chosen to participate in the Collective on the basis

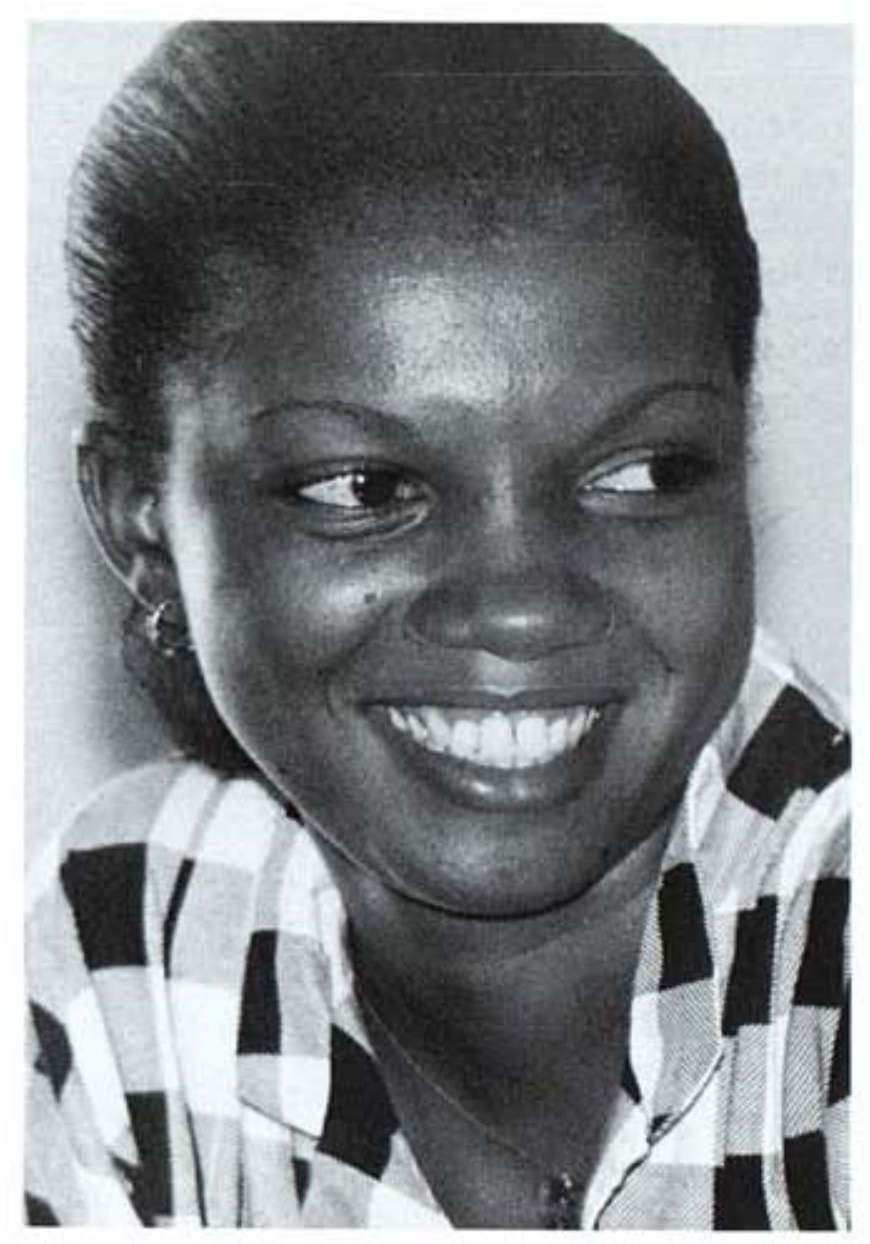

of literacy and numeracy tests as well as input from leaders of the local youth club.

It was decided to select women from a single community as this would provide a strong basis for cohesion among the women in the Group. They would know each others' strengths and difficulties and could help each other with practical problems, such as child care. They would also know the Community Liaison Officer, who acted as an important anchor for the Project, particularly in the early stages. For example, when a woman had problems with her "baby father," she would talk to both the man and the woman. She also made sure that the community was kept informed about the project.

The majority of the original recruits also belonged to the Tivoli Community's Ultimate Youth Club. This Club is managed mainly by men who, fortunately, recognized the importance of developing new employment options for women and agreed to support the project from its inception. They provided ongoing assistance in organizing fundraising events and also attended some of the Collective's early meetings. The 
support offered to the women by influential members of the local community was very important. It made their attempt to enter a male-dominated field not only credible but legitimate. People such as the Youth Club leaders and the Community Liaison Officer talked about the project in the community and portrayed the women as pioneers and examples of strength and determination.

\section{Training}

Overall, the training aspect of the project can be broken down into four phases:

- October 1983, Phase One begins at VTDI with 10 women;

- January 1984, Phase Two begins with five women initiated as part of the CRDC's Building Maintenance Program;

- May 1984, Phase Three begins with 15 women recruited from newly selected communities; and

- June 1984, four additional women receive training at CRDC.

On the basis of initial research, the experience level of the Collective members and the funds available, it was decided that trainees would begin with a five-week masonry and carpentry training program. This would consist of three components: practical tasks, classroom sessions and instruction by visiting lecturers experienced in the industry. This basic training would then be followed by a wide range of skills upgrading programs, developed in response to needs.

The ten women who arrived at the VTDI Building Department in Kingston early one morning in September, 1983 resembled anything but a potential gang of construction workers. They wore shoes suited only for a dance floor, wore stockings of the sheerest material and, with a few exceptions, giggled nervously behind their hands as they were asked to introduce themselves to the team of instructors. They were all between 17 and 25 years of age, from Tivoli Gardens and had completed at least a grade 9 education. All were numerate, literate and physically fit, and most had borne at least one child by the time they were 17 . None had ever considered looking for employment in the building and construction industry. It was difficult to imagine that within five weeks these same women would be prepared to start work as trade helpers on large construction sites. By then they would have developed basic building skills and an understanding of building terminology. And if they were successful in finding a job, they would be guaranteed take-home pay of at least twice the minimum weekly wage and a chance to become skilled tradeswomen.

Getting right to work, the training began with an exercise of the most practical kind: the VTDI Building Department had no bathroom or changing facilities for women. Thus the women's first task was to partition the existing male facilities so that they would have access to their own washing and changing area. During this process a substantial number of stockings were ruined and within a few days the physical appearance of the women began to change. Jeans and sneakers replaced skirts and sandals and work began in earnest.

In addition to hands-on experience, there were classroom sessions on topics such as accurate measurement, estimation, and correct mixes for mortar and concrete. Each woman had to build a concrete block wall using a trowel, hand hawk, plumb-bob and spirit level. The wall had to be rendered correctly and finished neatly. In addition, she had to saw up wood for making building formwork and construct a correctly jointed stool.

Both male and female visiting lecturers spoke to the women on various topics. A woman contractor introduced some of the practicalities of working as women on a building site. Questions about changing facilities, keeping the respect of men and dealing with menstrual cramps were discussed. This woman operates six of her own companies, ranging from a building and contracting company to a manufacturing plant for gas cylinders. She therefore provided a formidable role model. Since her initial participation as an instructor, she has also sponsored booths for the Collective at trade fairs and she supported the training of one member at the College of Arts, Sciences and Technology (CAST).

Another lecturer, a prominent male contractor, is also an ongoing supporter of the Collective. He spoke on career options, which later led to all the members taking a 


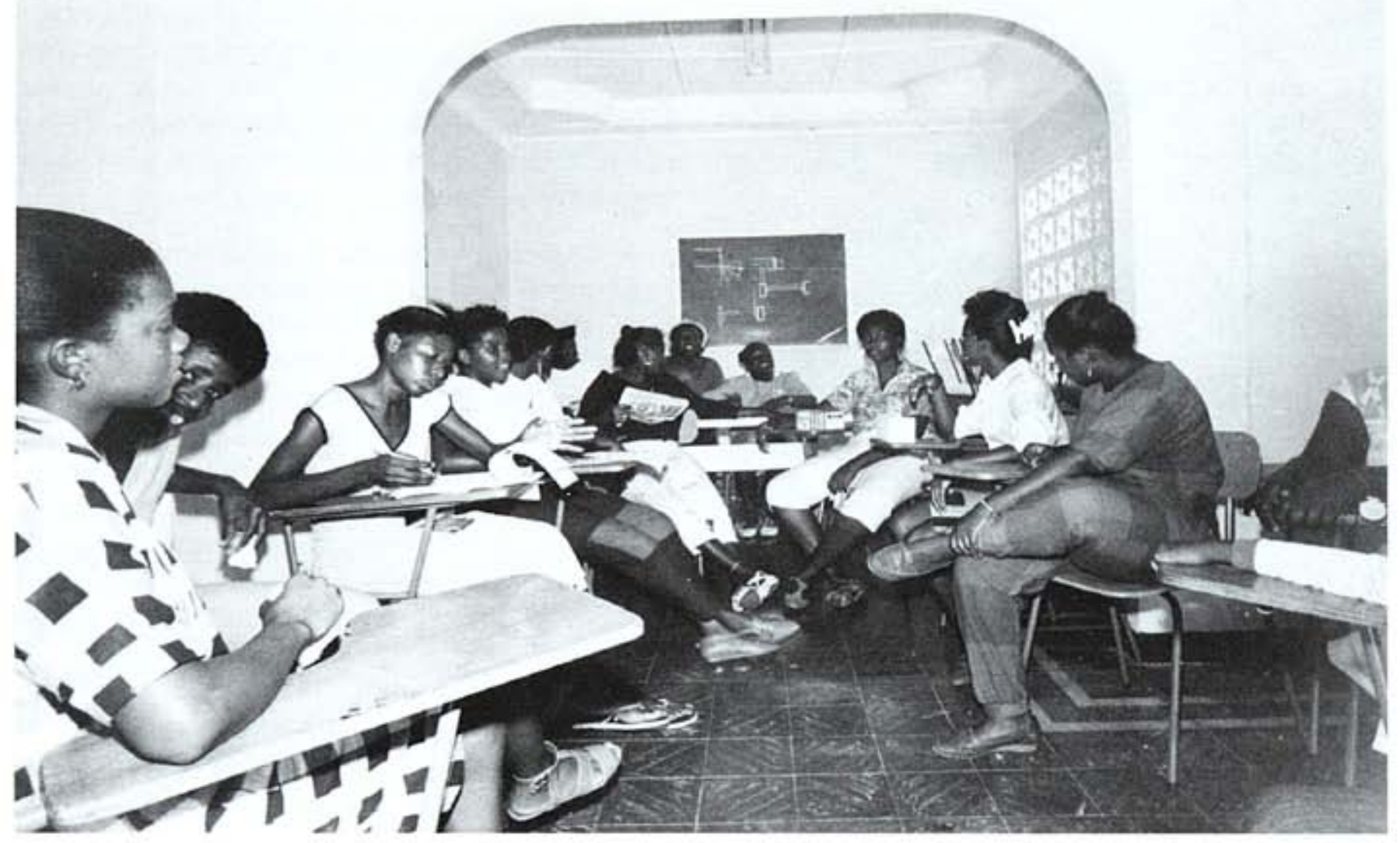

tour of the offices of engineers, quantity surveyors and builders as well as to a building component factory and at least three building sites.

Halfway through the training, most of the women had completely changed their idea of the building industry. As one woman put it, "I thought it was just laying blocks and digging trenches. I didn't realize there were all these other jobs - I mean even computer work."

Pauline dropped out of school two months before graduating, pregnant with her first child. She then tried commercial college, but had to drop out when her baby father got sick. When he left for the United States, Pauline became fully responsible for her child's support and started looking around for work. She heard about the Collective because "all her friends were talking about it," and decided to join with the second group of entrants in Phase Two.

Pauline has spent 10 months working on a large construction site, building a new training facility for building-skills trainees. If she were a man, she would be eligible to attend this institution on a residential basis. However, as a woman, she cannot attend. Asked about her experience in construction, Pauline replies: "It has been real good for me. It has more career possibilities than the sewing I did before. If it wasn't for the Collective, I wouldn't have (got involved) in construction because there wasn't anything to involve women in work like this."

During training the women were expected to work hard. If they were persistently late or absent, or became pregnant, they faced expulsion. They would never survive on a construction site if they were not disciplined and physically tough. No trainee allowances were provided other than lunch and enough money to pay for a bus ride to VTDI and home again each day.

After the first training program for Phase One recruits, the training received by members of the Collective took many different forms. The basic objective was always to develop skills of the kind and to the level that the industry could use. The three basic components of the training remained the same, but as women were recruited from 


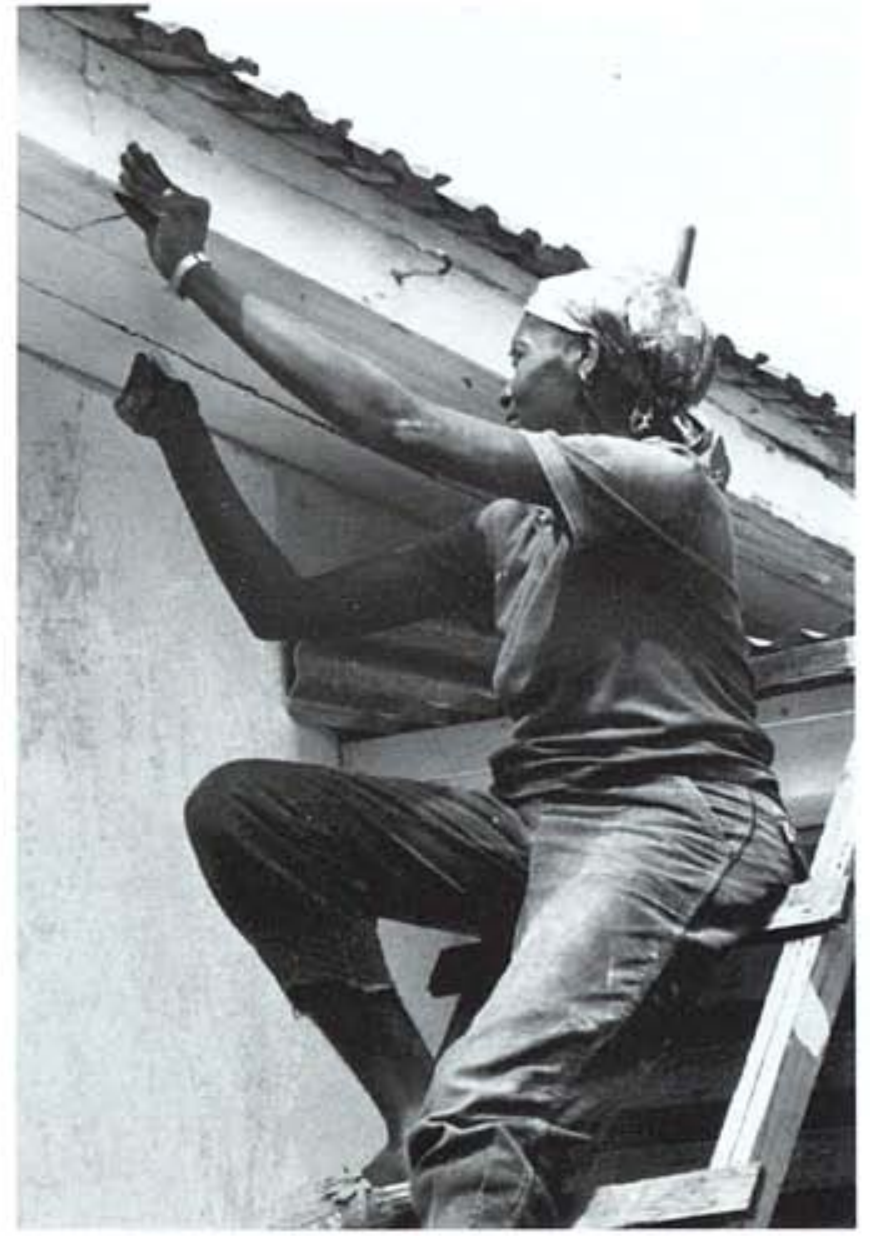

other areas, the program was changed to adapt to their needs and to the changing demands of the industry in order to optimize the use of available resources.

\section{Placement}

While the first 10 women were being trained, an agreement was reached with contractors to place them as trade helpers on a Government market upgrading project. This project involved refurbishing of several downtown Kingston markets used by vendors (almost all of whom are women) who bring produce from all over the island. The market facilities are extremely old and the upgrading project was aimed at improving sanitation, lighting, ventilation and stall space. Since the chief architect was a member of the Working Group, and the project was in an area sharing the same political alliance as Tivoli, the women's involvement might not be resisted on political grounds. The contractor had agreed to take the women into the regular labor force, pay them the same rates as male trade helpers and allocate them work with subcontractors. However three weeks into the training program major budget cuts by the Government led to the indefinite postponement of the market project. In terms of placement, the project was back to square one.

Training ended toward the end of November and with the approach of Christmas, arranging job placements became difficult. The Collective members agreed to meet on Sundays at the Tivoli Community Center. As December progressed, the mood became more and more depressed. However, the Collective soon developed a new strategy for finding placements through "job auditions"-offers to work on-site on a trial basis at no cost to the employer. If the employer was impressed and offered a long-term placement, the auditioner would be paid for the time already worked. If, on the other hand, the auditioner did not perform satisfactorily, the contractor would be under no obligation to pay her.

A number of contractors were contacted and asked if they wished to audition members of the Collective. In mid-January, the woman contractor who had participated in the training responded. She offered to hire two women on a trial basis for a housing project in Spanish Town, 12 miles outside Kingston. Two women with excellent technical evaluations from VTDI were there the following Monday, complete with new trowels and measuring tapes provided by the Collective. By the end of the week, they had been taken onto the regular work force.

Soon afterwards the male contractor who had addressed the trainees offered to try four women on a site in Kingston, building middle-income housing units. They began regular work almost immediately. At last it seemd the job drought was over. Every woman who auditioned after that got a job.

One problem associated with this strategy is deciding who should be chosen to attend a job audition. At first, with only 10 women, the selection could be handled easily on the basis of technical performance during training. As the Collective became more diverse, however, a system was needed. Thereafter women without job experience were given first consideration for placement. 


\section{SUMMARY OF TRAINING AND PLACEMENT \\ PHASEI PHASEII PHASEIII PHASEIV TOTAL}

Initial Training

5 weeks 12 weeks
full time part time
VTDI

5 weeks 12 weeks

full time part time

plus 6 weeks plus 6 weeks

"live" project "live" project

$\begin{array}{lllllr}\text { Tivoli Community } & 10 & 5 & 6 & 1 & 22 \\ \begin{array}{l}\text { Nannyville Community } \\ \text { Glengoffe Community }\end{array} & & & 4 & 3 & 7 \\ \begin{array}{l}\text { To be Placed } \\ \text { Drop Outs }\end{array} & 2 & 1 & 5 & & 5 \\ \text { Masons } & 7 & 3 & 9 & 0 & 4 \\ \text { Carpenters } & 1 & & 2 & & 19 \\ \text { Plumbers } & & & 1 & & 3 \\ \text { Electricians } & & 1 & 1 & 2 & 3 \\ \text { Steelworkers } & & 1 & 1 & 2 & 3 \\ \text { Painters } & & & 1 & \end{array}$

(A major attraction of construction work as a possible employment area was the potentially high wages even at the entry level. For example, entry level masonry and carpentry helpers earn a salary of J\$100 per week, while the official weekly minimum wage in Jamaica is $\mathrm{J} \$ 56$ per week and the average pay for a woman doing domestic work is $\mathrm{J} \$ 50$ per week. One Collective member began work as an industrial painter at a starting wage of J $\$ 500$ per week. Generally construction helpers can expect to be earning $\mathrm{J} \$ 125$ per week at the end of one year. Overall the monthly income of Collective members ranges from $\mathrm{J} \$ 400-2000$ per month. As of January 1986, J\$56.00 = US\$10.00.)

\section{Expansion}

Soon it became apparent that the rising demand from employers justified expansion of the project. Five more women joined the Collective in January, but still there were more jobs available than women to fill them. In February, 1984, the Collective was asked to provide 10 to 15 women for a factory building project. However, to further expand the
Collective would require additional human and financial resources. A number of critical decisions needed to be made regarding the Project's further development. For example,

- How would new participants be selected?

- What kind of organizational structure would permit the Collective to cope with an increasing membership?

- How could the Collective become independent and self-sustaining in the long term?

The Collective could have expanded its membership with new recruits from Tivoli. This, however, would have resulted in the Collective being clearly identified with the political party to which the community was allied - the Jamaica Labour Party (JLP) and would make the Collective vulnerable to charges of political partisanship, which in turn could threaten its long-term developmental prospects. Another alternative would have been to advertise for new recruits on an open basis. This option was rejected because the experience of the Working Group indicated that a strong community base can greatly increase the ability of women's 
groups to develop cohesion. A third option was to identify specific new communities for recruitment.

The Collective finally agreed that the best approach would be to identify additional feeder communities with different political affiliations. A proposal outlining this approach was presented to the Canadian International Development Agency (CIDA). In the meantime, a local foundation, the Grace Kennedy Foundation, helped with a short-term grant of $\mathrm{J} \$ 5,000$.

In making the decision to expand the project to other feeder communities, selection criteria had to be spelled out.

- The communities would have to demonstrate high female unemployment rates, particularly among younger women with dependent children.

- They would have to demonstrate identifiable and sympathetic community leadership (formal and informal).

- They would need to have a local meeting place available for use by women joining the Collective.

- They would have to be within reasonable distance by bus of the training institution and the areas where construction jobs are available.

- Ideally one of the communities would be as strongly identified with the opposition political party - the People's National Party (PNP) - as Tivoli was with the JLP.

The final decision to expand coincided with the arrival of a new volunteer resource person who offered to assist with the management of the project over the next year. Her major role would be the monitoring of up to nine different construction sites in geographically separate areas.

By May, the funding from CIDA had arrived, the new co-manager was in place and expansion could begin. Two new communities were selected to participate in the Collective: Nannyville, a housing settlement built within Kingston city limits in the 1970 s by the PNP Government, and Glengoffe, a rural community about 15 miles outside of Kingston. Nannyville met all the criteria, including political allegiance to the PNP. Glengoffe was selected as a result of approaches made by a community worker who was developing a women's horticultural pro- ject. This project required that women be trained to construct and maintain plant houses, but did not have funds to design a special training program. The Collective therefore decided to include five women from Glengoffe, at least on a temporary basis. (While it was felt that Glengoffe was geographically too remote to make access to work sites easy, the horticulture project should have absorbed the women's labor. As it turned out, this project was not implemented and these women also ended up in need of job placement.)

There were some political concerns as expansion began about possible violence to PNP supporters entering Tivoli or JLP supporters going to Nannyville. Initially it was assumed that two separate collectives would be required. This division, however, was adamantly opposed not only by the new recruits but by the Collective's original members. At the women's insistence the Collective remained a single entity. It now holds its monthly meetings on neutral territory at the CRDC offices. As one of the members puts it: "We don't have any business with tribal politics. Let the men have that, we women have had enough."

"Before I became a member of the Women's Constructive Collective, I was at home suffering from the frustration of depending on my family for whatever I needed for my use, not able to obtain a job and thinking of what I could possibly do to make myself independent."

Sharon was 25 years old and the mother of two children when she joined the Collective. She has always been very close to her grandfather who encouraged her to make little trucks and fix things with his tools. Her father worked in construction too, and used to take her with him to visit building sites. When Sharon first told him about the Collective, he laughed, but he is pleased now when she talks about one by twos or two by fours. "If I had been a boy, I would have been working at the Public Works Department helping to patch roads, but Public Works does not seem to really employ women except as secretaries. 


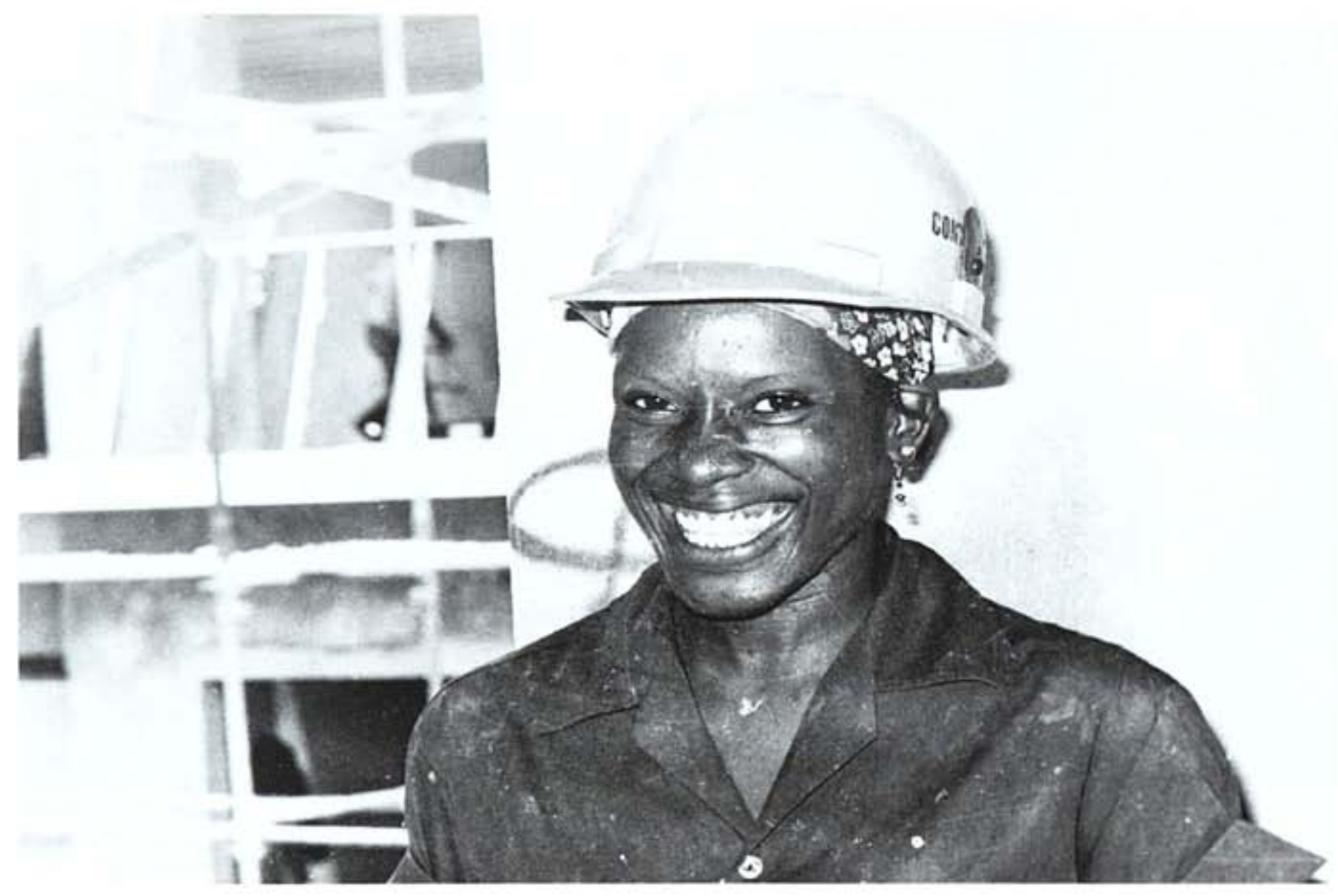

Her baby father "talked against" her joining the Collective so, "I told him I was just nailing a few nails and didn't tell him anything about the cement. When I took home the stool I made, he started calling me carpenter and now, when anything wants to fix, they ask me to do it."

Sharon has learned how to put up an entire wooden house and to use electric drills, squares, sledge hammers, saws and hammers. She laughs when she says, "I never thought of myself hitting down walls and all that, I really enjoy it."

Sharon joined the group in the third phase and comes from Nannyville. She feels strongly about the unity of the Collective. "We're supposed to be close to each other as sisters - I don't see where politics comes into our bracket. I don't see where it would help us. I think it's good that we're women from different political areas - all mixed up."

By June 1984, nearly one year into the project, the members of the Collective decided that further expansion of the Collective's membership might be unwise as there were clear signs of contraction in the building industry. Housing starts declined by over 30 percent in 1984, and the Ministry of Housing's budget was cut from thirty million Jamaican dollars to J\$100!!! Instead it was decided to consolidate and focus on further skills development for the women already in the Collective. There was still a long way to go before any of the women could really be considered "skilled" and able to work without supervision. However, this approach also would require further resources. Funds needed to carry out the skills upgrading program were secured from the InterAmerican Foundation.

\section{Organizational Structure}

Since 1984, the CRDC has served as the "parent organization" for the Women's Construction Collective. CRDC administers the international funding, hires personnel, and provides office space, as well as a structure and legal framework for the Collective until it became an independent legal entity. 

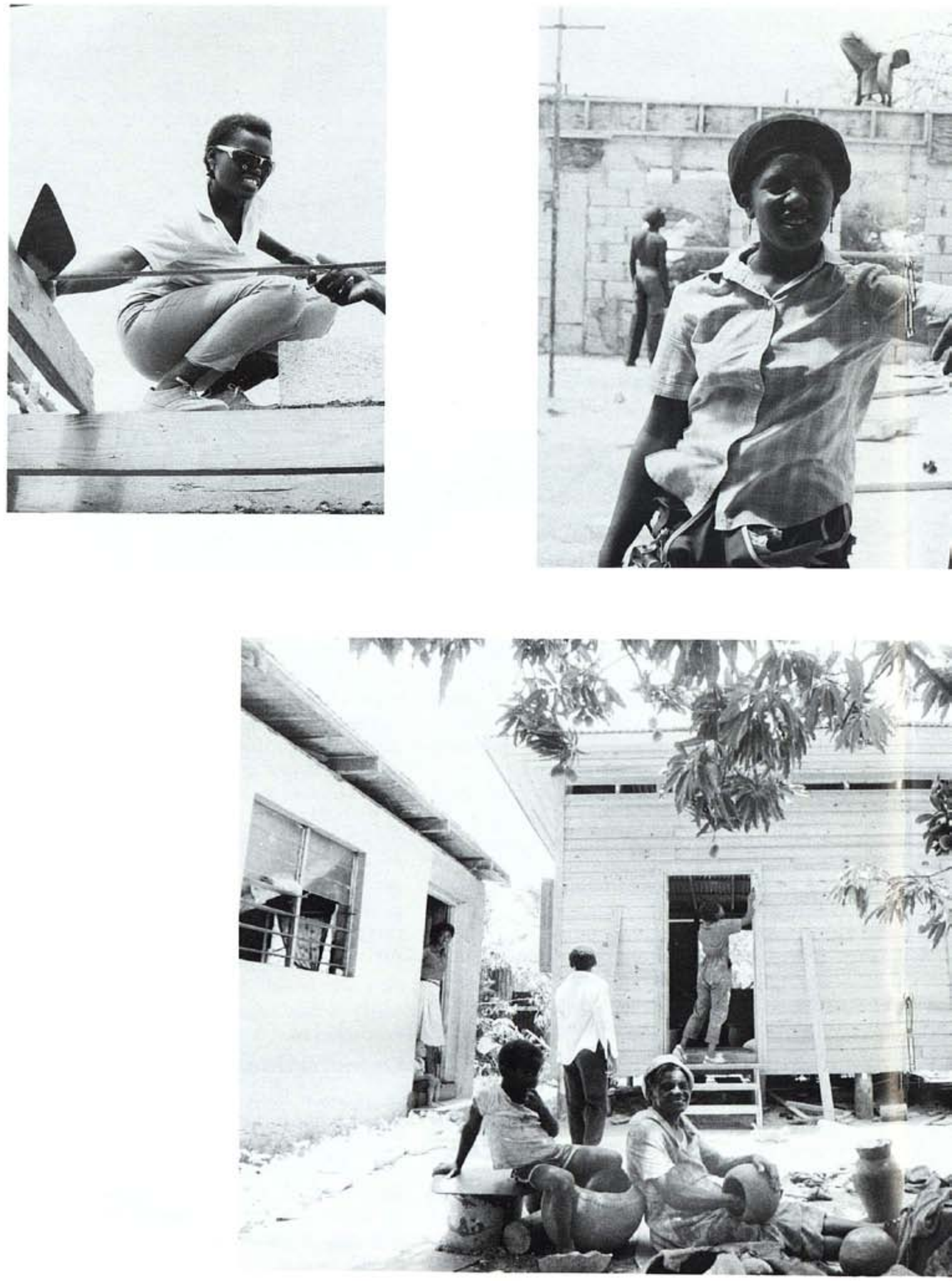
The process of expansion led to a redefinition of the role of the Collective and the creation of a new organizational structure. The challenge was to increase the Collective's ability to govern itself and gradually decrease the need to rely on the judgments of the coordinator and the co-manager, thus enhancing the capability of each woman to play a responsible role.

The question of dependency has been a critical issue since the Collective's formation. The first group of women spent a considerable amount of time discussing the issue and actually expelled one woman from the group because of her almost total passivity and inability or unwillingness to take responsibility. A good example of this problem was the enormous effort required to open a bank account in the Collective's name. After the Project had been operating for three months, the coordinator refused to go to the bank to get the necessary forms, arguing that the members should allocate that responsibility among themselves. Several women were eventually selected to deal with the banking matter, but it was two months before they coordinated their efforts sufficiently to open a standard bank account (that could have been opened in 10 minutes by the coordinator). By the end of the two months, however, at least a few members had learned how to deal with bank personnel and how to open a standard bank account.

One of the results of the attention focused on dependency was the Group's decision to set selection criteria for new recruits entering Phase Three of the project. The objective was to weed out early those who were not highly motivated. As part of the selection procedure, the members designed two test papers, one in English and one in mathematics, that every potential recruit would be required to take. The tests included a question asking the applicant why she wanted to be a construction worker as well as specific questions relating to estimation and measurement using building examples.

Initially the women elected a single gang leader, who chaired meetings and acted as the Collective's spokeswoman, a secretary and a public relations officer. In addition, most women working together at a particular construction site would also select a site gang leader to represent them with the employer and to speak for them at monthly meetings. One group developed an informal, revolving system of representation.

By the end of the first year, the Collective's gang leader and the secretary were complaining that everything was being left to them and that "the women are cussing us and giving us a hard time when we ask them to do things. "The Collective as a whole therefore agreed to appoint a formal Executive Committee with clearly defined job responsibilities. As a result, the Collective now has an active Executive Committee of five women who meet on a regular basis with the project coordinator.

Millicent is President of the Collective and is also one of its youngest members. She was only 18 when she joined the first phase. She lives with eleven relatives in a two-bedroom apartment in Tivoli, but spent much of her childhood with an aunt who is a farmer.

When she first heard about the Collective, she thought it was a "bit weird," but decided she might as well try it. "Being made gang leader was a real challenge. I knew it would mean a lot of trouble because some of the girls love a 'long argument.' When we started to pay money into the tool fund and put on activities to raise money, there were a lot of problems. Everybody seemed to have an excuse for not doing something. But one of the things I like about the group is that everyone is open and we can talk things out."

Millicent walked three miles to get to her first building job. "I was a bit scared at first because the men looked rough, but after talking with them, I felt different as they always wanted to work with us. When the mason men did not come, we helped casting. We filled the first foundation and laid the first set of blocks. When the mason men came the next day, they were amazed and said they did not know women could do it." 


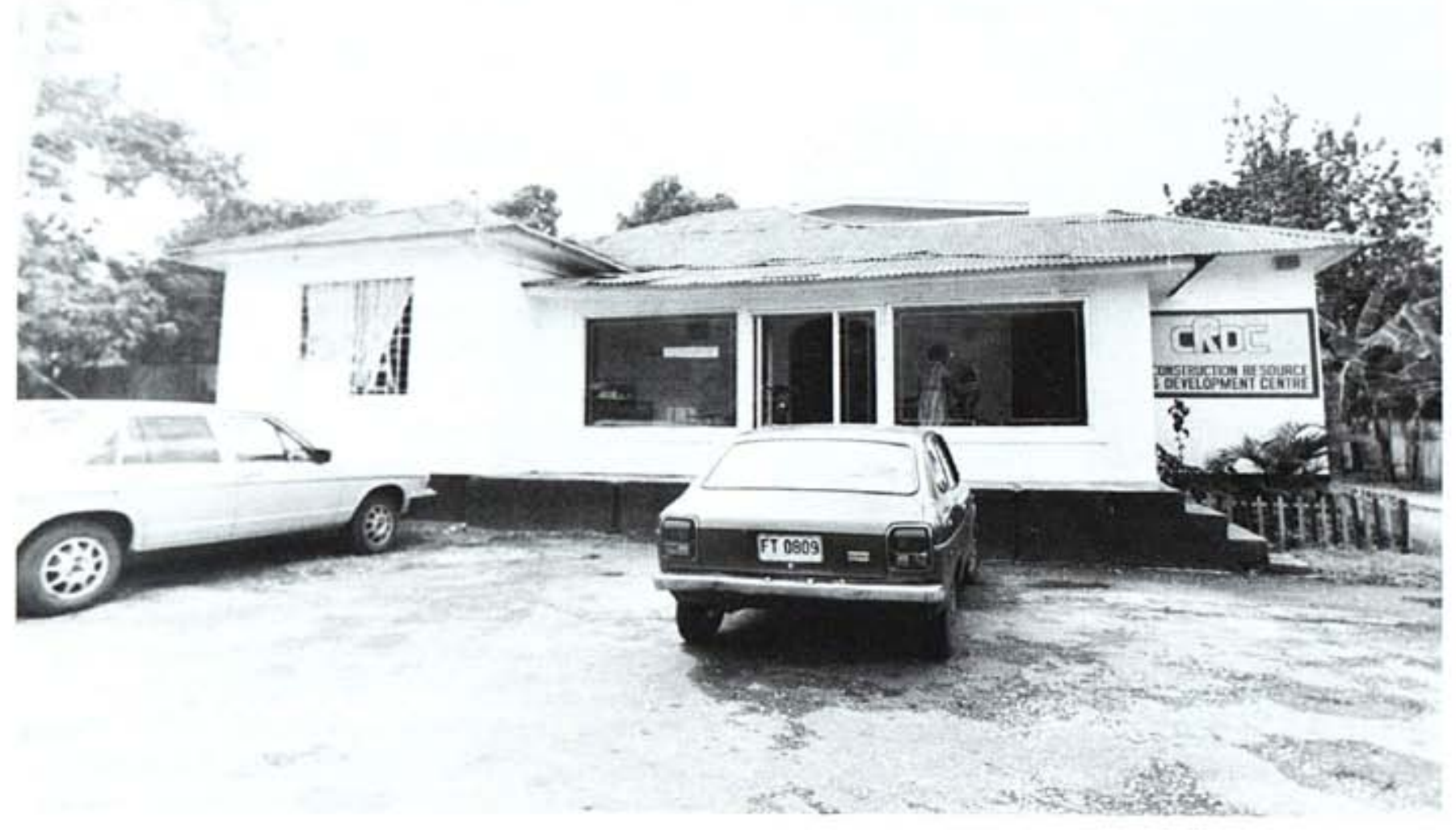

The transition of the Collective as a whole from dependency on outside management to independence is taking place relatively slowly. Initially the project coordinator made most of the key policy decisions regarding participant selection, training content, job placement, etc. When the co-manager joined the Collective, it was decided to select two members as trainee managers. One women had been the gang leader and now serves as the Collective's President. The other woman had joined the project during the third phase and came from Nannyville.

When the co-manager left the Collective after one year, it was agreed that the time had come for the members themselves to take over the day-to-day management of the Collective. The trainee managers have now moved into the old co-manager position, taking charge of bookkeeping, placement, site monitoring and other organizational tasks. They are assisted by other members of the Collective's newly appointed Executive Committee.

\section{New Directions}

One move to encourage greater independence has been the establishment of the Collective's own business: a repair and maintenance business and a carpentry workshop. Women who are not employed with contractors rotate through the business in five to eight-week cycles, either in the workshop building wooden components such as doors, shelves, windows, etc., or carrying out repair work throughout the Kingston area. The workshop is run by a male carpenter employed by the Collective, while the repair work is done "on the road," supervised by a former government building skills instructor.

The repair and maintenance business emerged in response to a clearly identified need for firms able to carry out small-scale domestic repairs such as rehanging or replacing doors, fixing windows, installing shelves and so on. Also, many female clients tend to feel more secure about letting women into their homes. This project-based training pays for itself out of business fees. Each woman is paid as a trade helper during her training, according to rates established in the industry, and is expected to carry out an individual project such as making an item needed by the Collective. The business' earnings go into the Collective's fund. The workshop building, for instance, was constructed by the Collective with money made 
when the business built a wooden house for Ma Lou, one of Jamaica's famous potters.

Initial funding for the business came from Inter-American Foundation funds, which allowed for upgrading of training and provided equipment and two vehicles. The latter reduced the dependence of the Collective on the one or two people able to drive the CDRC's pick-up truck and has encouraged more women to learn to drive.

Now that the Collective is operating on so many levels, the need for effective coordination is becoming much greater. Recently CRDC staff and the Women's Construction Collective members involved in the workshop, the repair business and the office agreed to meet on Friday afternoons for an open "rap session" to discuss the previous week's activities and to allocate tasks for the coming week. There is little question that both the organizational structure and the administrative framework of the Collective will continue to change and adapt to new developments over the next two or three years, before settling into a permanent form.

\section{Support for the Trainees}

The industry focus of the project appears to have been largely responsible for the high placement rates achieved, but the emphasis on community participation and support that accompanied it proved no less important in laying a strong basis for cohesion among Group members. The community support system played a crucial role in helping the women in their transition from unemployment to nontraditional employment in the male-dominated world of construction.

Family support was also needed, but not always forthcoming. This took time and education. As current Collective President, Millicent Powell, said: "At first my parents were not in favor of me doing construction work because they spent money on me for business study." Other women described how their families thought they were joking and that they could not seriously be considering working as construction. workers: "Everybody knew that was a man's job."

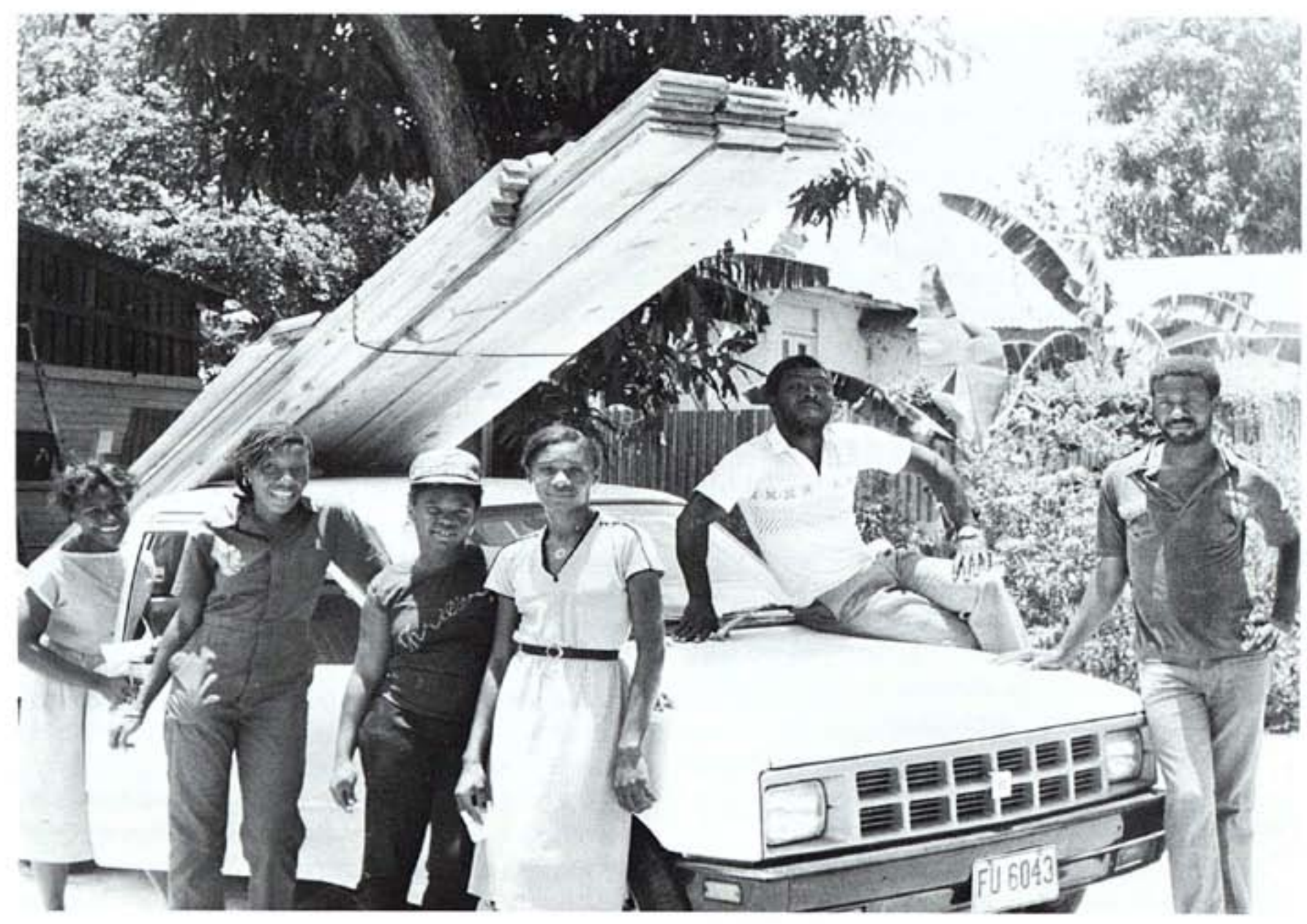


Some women were even prevented from joining because their baby fathers "did not want two men in the house." Two relationships were broken off as a result of the conflict.

One of the interesting findings of a university student who interviewed members of the Collective was that they had received far greater support from female members of their families than from the males. This support also appears to have come from women in church groups. In contrast, one male pastor was totally against the project because it encouraged women to "wear pants."

However the strongest psychological support system was probably provided by Collective membership itself. The Group meets one Sunday each month. Not only do the women share their experiences on the job and the reactions they receive at home, but they also organize group events, such as team sports and outings, that increase the Collective's cohesion. The Collective also initiated a public awareness campaign through local newspapers, on television, radio and through a video showing the women at work and talking about their experiences, which also describes the training model used by the Collective in its early stages.

Women require not only the will to enter a nontraditional field, but also the financial means. It is practically impossible, for instance, to get a job as a carpenter's helper if you do not have a saw. For this reason, the Collective runs its own revolving tool fund. Each woman is loaned tools to job audition. If she gets the job, she keeps the tools and, as she begins to earn income, repays the cost into the tool fund. She must repay in full in order to be eligible for further loans or for sponsorship in additional training programs. The tools are not so costly when purchased in bulk and the operation of a revolving loan fund in an interest bearing account ensures that new tools can be provided on a credit basis without requiring collateral.

Nowadays a member of the Collective who wants to participate in a skills upgrading program can approach the Executive Committee. If they consider that the training will be beneficial both for the women and the Collective, and if the necessary loans

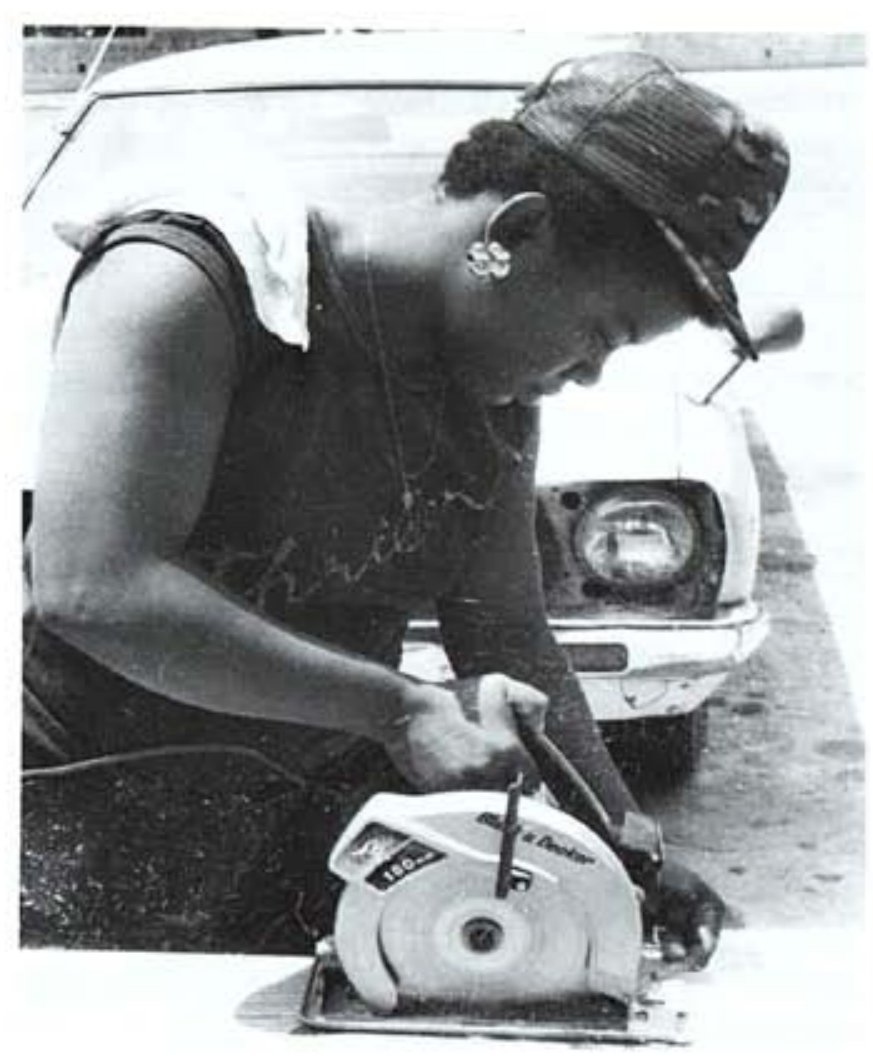

are available, then the applications for training will be approved.

The Collective also provides the women with bus fare to attend monthly meetings and any training for which they are sponsored. This is particularly important for the women who may not be working because they have not been placed or are between jobs. Occasionally the Collective fund, which is managed by the Executive Committee, has been used to give loans for health and child care, but this is very unusual and is not encouraged as the Collective does not aim to become a welfare system.

\section{Results}

Lurl joined the Collective in May 1984. having passed through the selection procedures developed by the original members of the Collective. Her first task as a member was to introduce herself, which she did while giggling and covering her mouth so that much of what she said was inaudible. It finally emerged that she had not completed high school, had two children to support 
and had never been employed, but wanted to be a beautician. Failing to find opportunities in that field, she was prepared to try anything that came up. What came up was the Women's Construction Collective. She started training in Phase Three.

When the five week training period was up, there was no job immmediately available for Lurl due to delays in implementing a particular building project that was to have employed her. Instead, she started on-site with 10 other women who worked unpaid for six weeks to refurbish an old wholesale liquor store that was to become the CRDC and the WCC's center. In the last week of this exercise, the Collective was asked to send two women to interview for a maintenance job with one of the large bauxite companies. Lurl was the first to arrive at the interview and started work the next week, earning the highest wage any of the members has ever earned.

Shortly afterward there were rumors, later confirmed, that Lurl had moved out of her community. Lurl had left her baby father. One of eight children from a poor rural family, by the time she was 14, Lurl's mother could hardly cope with the economic burden of supporting her family. The burden was eased by moving Lurl in with a male benefactor who agreed to pay her way through school. By the time Lurl was 16, she was pregnant by her "benefactor" and out of school. At 18, she was already the mother of two children and being beaten regularly by the man on whom she was economically dependent.

As a result of her experience, Lurl had no hesitation about packing her bags and leaving as soon as she had an independent income. Today she lives in another parish with her two children and a sister. Her work as an industrial painter is stable and her performance has been favorably evaluated by her employers, who are now considering employing other women on their maintenance team.

Sharon, Millicent, Pauline and Lurl have all had different experiences during their time with the Collective. While the longterm impact of the project on them and their families may be difficult to evaluate, other changes have been rapid and dramatic. As they found themselves able to earn their own livings in a male-dominated industry, they developed new confidence in themselves. All four of them have stuck with the projecttwo of them, between themselves, have turned down five job offers in more traditional areas. Many have become articulate spokeswomen for the Collective and all have learned a great deal about individual and group responsibility. In the course of two and one-half years, of those women who have left the Collective, four did so because of pregnancy. Two of these women claim to have been made pregnant against their will by their baby fathers who did not want "two men in the house." Neither of these women started work on a construction site and neither has returned to the Collective.

The impact of the Collective on the construction industry appears to be positive. This may be due to the early analysis which determined the needs of the builders at the trade level. The willingness of project participants to job audition, and thus prove themselves, certainly helped with placement. Reported decreases in violence and increases in productivity on sites where Collective members are working seems to be directly related to the positive perception of women's roles. Builders and foremen report that men almost automatically behave less abusively and violently in the presence of women. They also feel that both men and women tend to compete with each other on the job-the women working to show that they "could do the job as well as men," and the men trying to "always outdo the women" - a form of competition that almost inevitably boosts productivity. Another interesting achievement has been the ability of the women to move across political boundaries. Women from communities associated with one political party have been placed on sites identified with the opposition party without any serious problems.

As yet the women present no serious threat to male dominance on construction sites. They are few in number and have not reached the skill level where they can compete for jobs as subcontractors. In effect, they are still "bossed" by men and this may account for the absence of any serious resis- 


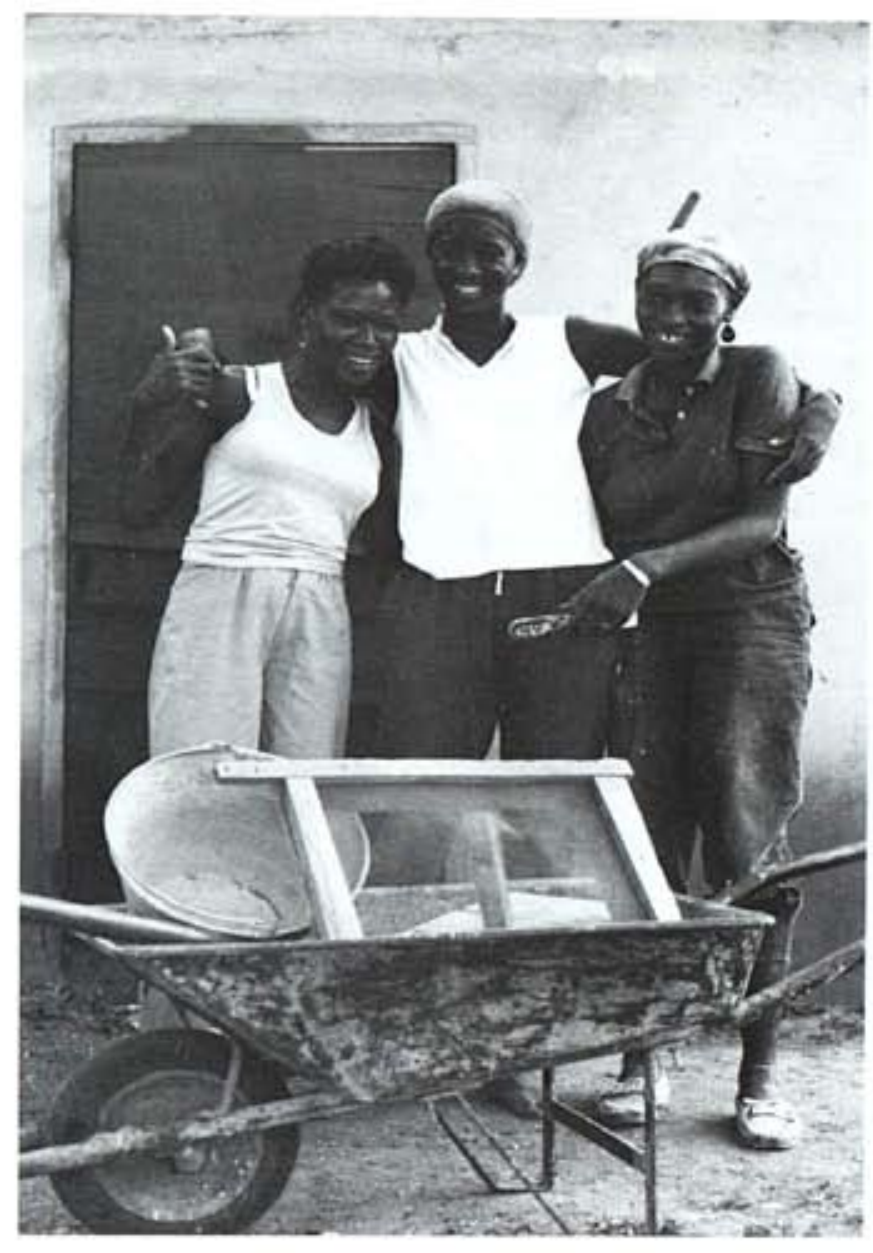

tance to them by their male co-workers. However, as jobs in the industry become more scarce, resistance is likely to increase. One women recently reported being threatened on-site by a man who declared she was taking away his job because he was a man and came from the "correct" political territory, while she did not. She seemed to think that the politics of the situation were more significant than the sex, at least in this instance.

On the other hand, the publicity that the project has received in the local media has made the concept of women working on construction sites increasingly acceptable both at the work place and in the community. This is demonstrated by the ability of the Collective's members to retain jobs and find new placements despite the serious slump in the industry and by the regular requests received for entry into the Collective.

While the entry of 34 competent women into the construction industry at the trade level may not seem significant, contractors who have employed Collective members report they are now employing other women. This may mean that some of the over 1,000 women who received building trades training prior to 1980 , along with those who may benefit from the introduction of the new residential training institutions, will now have employment opportunities. The Collective has also been excited by the interest shown in its activities by women's groups in other countries, largely as the result of the video tape produced to document the Collecctive's activities.

Overall, in the two and one-half years it has been in operation, the Collective has trained 34 women and placed over 90 percent of them in construction jobs in the areas of plumbing, masonry, carpentry, electrical installation, painting and steelwork. More than 15 Group members have also received further skills training ranging from driving a car to reading blueprints. Two women have completed the Construction Technology Course at Jamaica's College of Arts, Sciences and Technology (CAST), and two members have taken over day-to-day management of the project. In addition, the Collective has refurbished new office space for itself and the CRDC. Funding sources have 
been expanded and the project has launched its own business in order to develop an independent source of income.

\section{Looking Ahead}

The future of the Collective will certainly not be easy. Despite all the member's efforts, the effects of a major decline in the construction industry are bound to be felt, especially in terms of direct employment. The general economic recession has left potential clients with less money in their pockets. This has occasioned a search for new markets for the skills the women have developed and for ongoing skills upgrading opportunities. At the moment, it is still too early to say whether this approach will be effective, although it is clear that the experience gained in the workshop business is significantly raising the standard of the members' carpentry skills.

So far response to the maintenance business has been extremely positive, but its long-term viability has yet to be established and it is unclear how many women it will be able to absorb. As the business grows, greater formalization of the Collective's operations will be necessary. Therefore, as of March 1986, the organization has officially become the Kingston Women's Construction Collective, Ltd. - a legally recognized Jamaican company.

The Collective, however, is by no means independent as yet. The project as a whole continues to be supervised by the project coordinator and the CRDC continues to administer major funding, hire staff as needed through its organizational system, and provide office space.

Since its inception, the Collective has relied on overseas grant assistance. In May 1986, current funding from these grants will expire. The growth of the business as a significant source of income will be a major determinant of the Collective's self-sustainability. The membership feels strongly that the Collective should continue not only for the benefit of the women involved, but also because provision of entry-level skills and upgrading of building skills is still not available to women on the same basis that it is for men. As noted above, the Government has recently opened a central residential facility for training in building skills, known as the Port More Heart Academy. This institution will, in theory, accept women as day students. However, this in fact limits entry to women living within the immediate area. Ironically, six Collective members living outside of the immediate area helped to build this facility. One solution to this problem being considered by the Collective is to establish a hostel for women trainees near the institution. Another is the expansion of the Collective to include women who have already been trained in building skills but who have not been given access to the support systems that facilitate job placement and skill upgrading. Either option would require additional funding.

In facing these critical challenges, it is hoped that the interlinkages between the industry and the communities will continue to provide the flexibility that has been so central to the Collective's development.

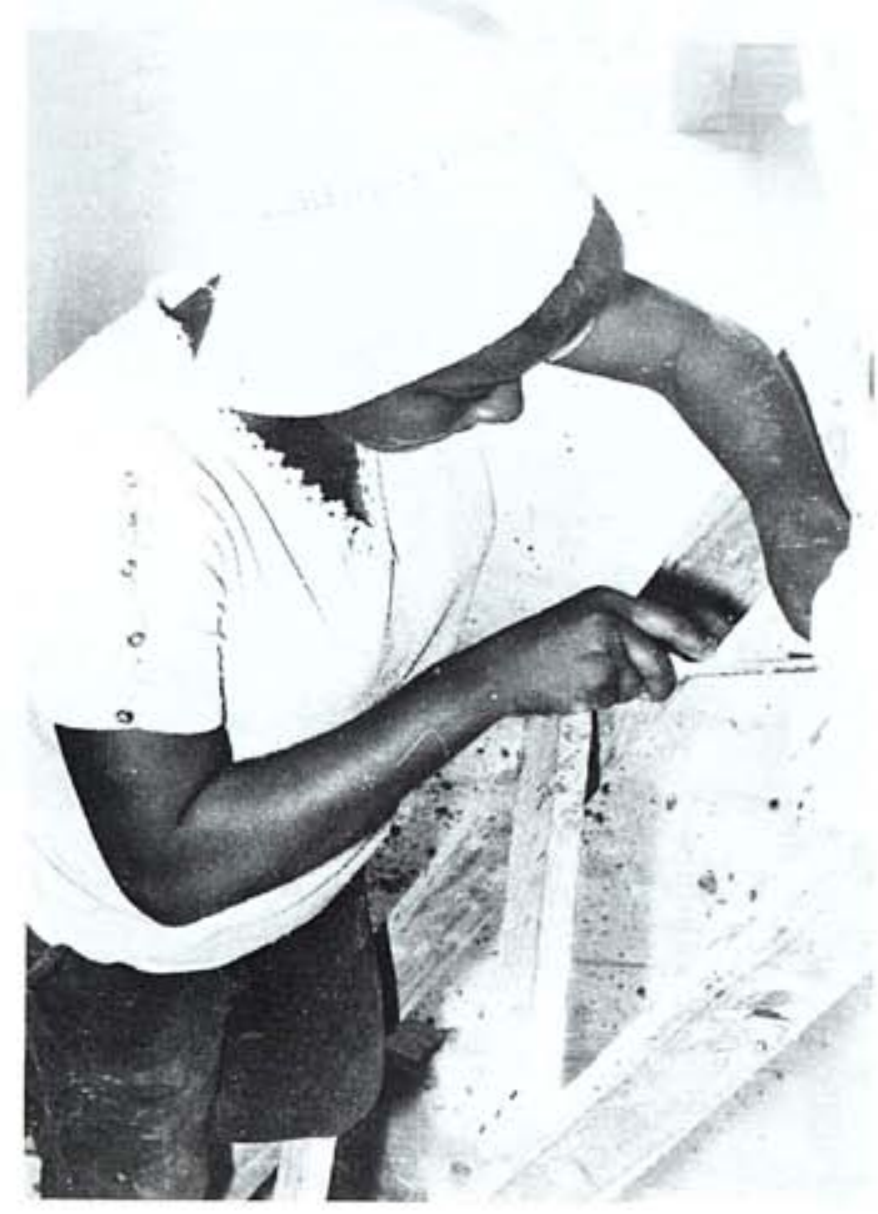




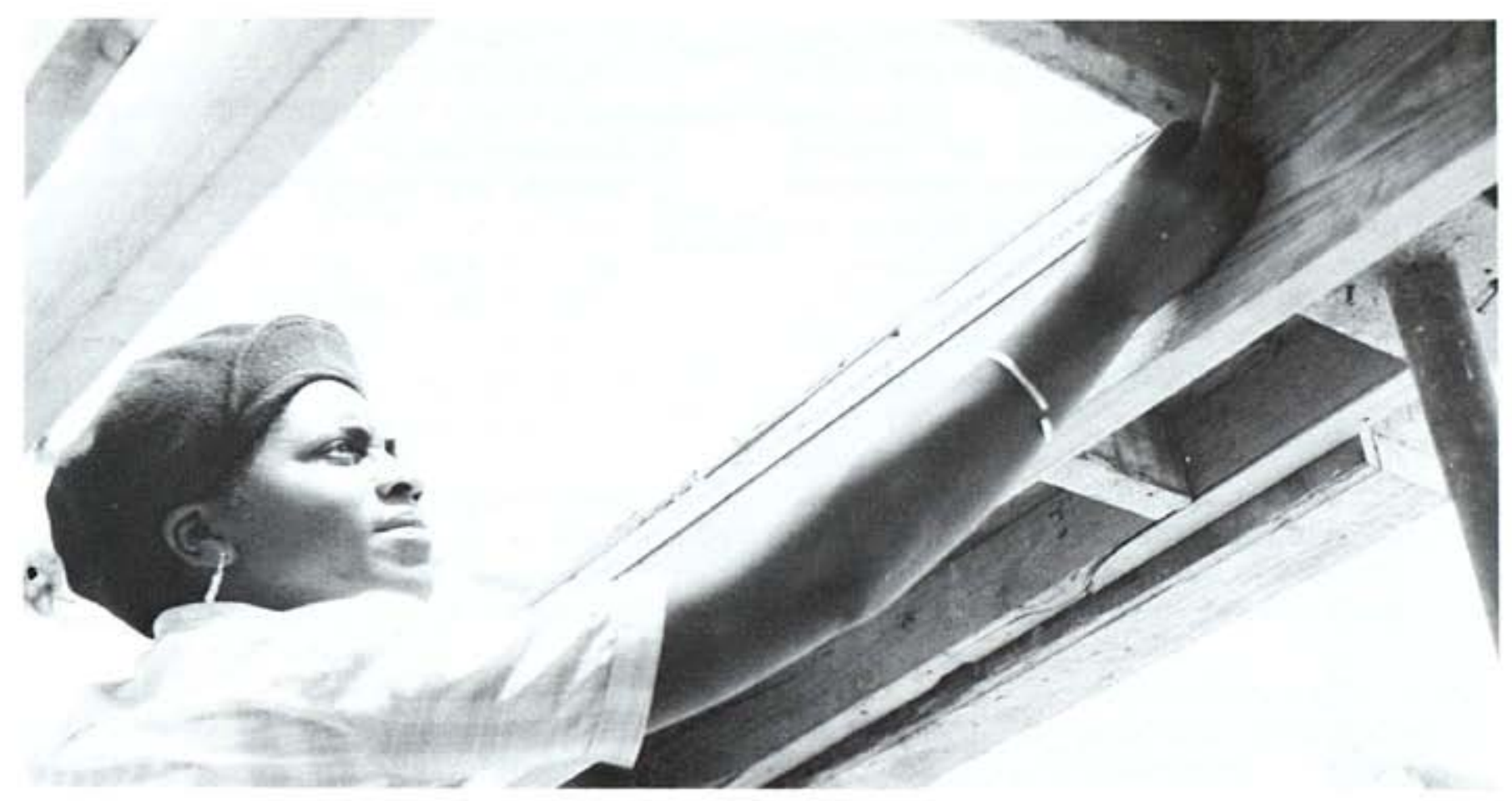

\section{Lessons}

1. A thorough analysis of the industry, particularly if it is one that does not traditionally employ women, is crucial. The trainees found employment because they had been trained for identified job openings at specific levels.

2. Women must have access to needed equipment without initial cost outlay in order to start work. In the case of this project, there would be no jobs available for women without tools. A revolving fund can ensure this access without requiring collateral.

3. Strong links to feeder communities through a body such as the Working Group provide a good basis for group cohesion. The Tivoli community worker and local leadership in Nannyville and Glengoffe provided ongoing support and motivation for the women, particularly in the early stages. The Working Group provided access to these support systems.

4. It is extremely useful to have access to individuals or institutions able and willing to provide "customized" training. A freestanding training program can be exorbitantly expensive and short-term training does not in itself justify expensive outlays for machinery and equipment. The Vocational Training Development Institute allowed project management to have significant input into training design while offering well-equipped and well-supervised facilities.

5. When working in politically volatile areas, a project should maintain a "neutral" political identity. The political neutrality of project management allowed for entry into the violently opposed political communities and for movement across territorial lines. This, in turn, allowed for cooperation between women from these various communities.

6. Projects often evolve in directions quite different from those anticipated in proposals to funding agencies. A good relationship with the project officer of the funding agency will allow for flexibility in both program design and use of funds. For example, after this project began, it expanded far more rapidly than had been envisaged. However, soon after money was mobilized to accommodate this rapid growth, the construction industry went into a slump and the project had to focus on consolidation rather than expansion. Dialogue with the various funding agencies allowed 
for the necessary changes to be made smoothly and according to decisions made by the Collective.

7. Development cannot be rushed. Women who have been dependent most of their lives need time to adjust to taking on responsibility. It took 18 months before any woman found a construction job as a result of her own initiative. It took two months for the Collective members to open their own bank account once a decision had been made to do so. If the project staff take the easy way out and do things for the group, a welfare mentality develops that stifles the growth of initiative. It is better to allow the necessary time for participants to work out a way to do things for themselves.

8. Documentation is worth all the energy and effort it entails. Detailed written and photographic documentation, together with the ten-minute video, made it easier for the project to approach funding agencies. It also allowed the project to "travel," both inside and outside of Jamaica, and hence widen its impact. The women's own energy, enthusiasm, and involvement is captured much more clearly on video and in photos than is possible in any written or verbal account.

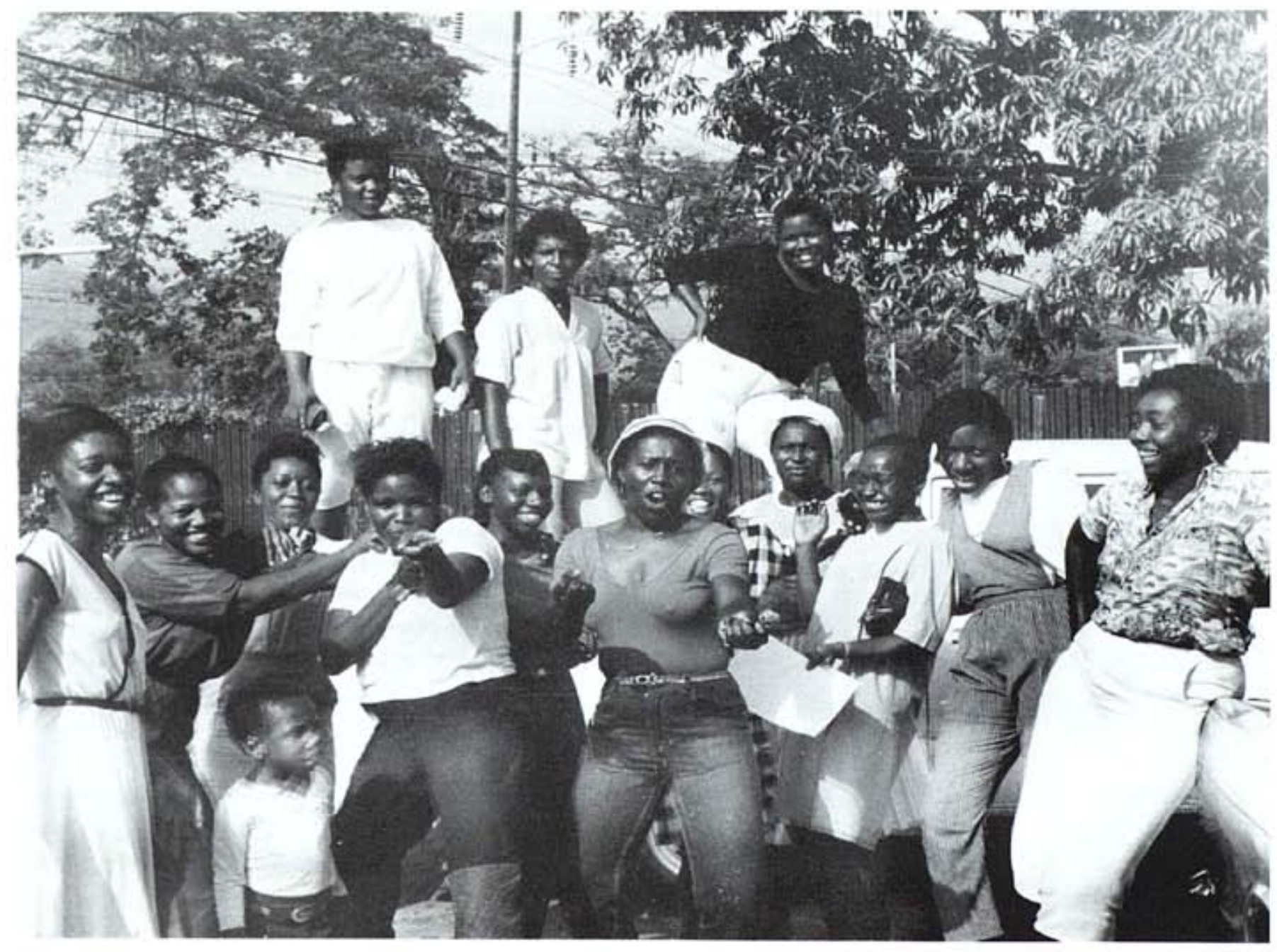




\section{Appendix}

\section{Training Summary}

\begin{tabular}{|c|c|c|c|c|}
\hline $\begin{array}{l}\text { Training } \\
\text { Program }\end{array}$ & Skills & $\begin{array}{l}\text { Type of } \\
\text { Delivery }\end{array}$ & $\begin{array}{l}\text { No. of } \\
\text { Women }\end{array}$ & $\begin{array}{l}\text { Additional } \\
\text { Information }\end{array}$ \\
\hline $\begin{array}{l}\text { Basic Train- } \\
\text { ing I (VTDI) }\end{array}$ & $\begin{array}{l}\text { Carpentry, } \\
\text { masonry }\end{array}$ & $\begin{array}{l}5 \text { days per } \\
\text { week for } 5 \\
\text { weeks }\end{array}$ & 10 & $\begin{array}{l}\text { Learned to carry and } \\
\text { lay blocks, build } \\
\text { complete wall and } \\
\text { render it, build simple } \\
\text { formwork and their own } \\
\text { wooden stool. }\end{array}$ \\
\hline $\begin{array}{l}\text { Basic Train- } \\
\text { ing (VTDI) }\end{array}$ & $\begin{array}{l}\text { Carpentry, } \\
\text { masonry }\end{array}$ & $\begin{array}{l}5 \text { days per } \\
\text { week for } 5 \\
\text { weeks }\end{array}$ & 15 & $\begin{array}{l}\text { As above, but with the } \\
\text { addition of basic } \\
\text { plumbing and pipe } \\
\text { fitting }\end{array}$ \\
\hline $\begin{array}{l}\text { General } \\
\text { Building } \\
\text { Mainte- } \\
\text { nance I } \\
\text { (CRDC) }\end{array}$ & $\begin{array}{l}\text { Introduction to } \\
\text { plumbing, } \\
\text { carpentry, masonry, } \\
\text { electrical, painting } \\
\text { and air } \\
\text { conditioning } \\
\text { maintenance }\end{array}$ & $\begin{array}{l}1 \text { day, } 1 \\
\text { evening per } \\
\text { week for } 12 \\
\text { weeks }\end{array}$ & 5 & $\begin{array}{l}\text { Not entirely satisfactory } \\
\text { as most trainees were } \\
\text { men with previous } \\
\text { experience. Best } \\
\text { compromise in the } \\
\text { absence of sufficient } \\
\text { funding for alternate }\end{array}$ \\
\hline $\begin{array}{l}\text { General } \\
\text { Building } \\
\text { Mainte- } \\
\text { nance II } \\
\text { (CRDC) }\end{array}$ & As above & As above & 4 & As above \\
\hline $\begin{array}{l}\text { Live Project } \\
\text { CRDC/WCC's } \\
\text { offices }\end{array}$ & $\begin{array}{l}\text { Carpentry, } \\
\text { masonry, } \\
\text { electrical }\end{array}$ & $\begin{array}{l}5 \text { days per } \\
\text { week for } 6 \\
\text { weeks }\end{array}$ & 12 & $\begin{array}{l}\text { Proved extremely } \\
\text { valuable in placement, } \\
\text { especially for women } \\
\text { who went into painting }\end{array}$ \\
\hline $\begin{array}{l}\text { WCC Carpentry } \\
\text { Workshop }\end{array}$ & $\begin{array}{l}\text { Carpentry, } \\
\text { painting, } \\
\text { estimation }\end{array}$ & $\begin{array}{l}5 \text { days per } \\
\text { week ongoing }\end{array}$ & $\begin{array}{l}2 \text { or } 3 \\
\text { at any } \\
\text { time }\end{array}$ & $\begin{array}{l}\text { Key resource person is } \\
\text { a male carpenter } \\
\text { Workshop pays its own } \\
\text { way so women also } \\
\text { learn some business } \\
\text { skills }\end{array}$ \\
\hline $\begin{array}{l}\text { WCC Repair } \\
\text { Business }\end{array}$ & $\begin{array}{l}\text { Carpentry, } \\
\text { masonry, steel } \\
\text { work, painting, } \\
\text { estimation }\end{array}$ & $\begin{array}{l}\text { depends on } \\
\text { the job }\end{array}$ & $\begin{array}{l}\text { variable } \\
2-7\end{array}$ & $\begin{array}{l}\text { Kinds of work varies } \\
\text { from building entire } \\
\text { wooden housing units } \\
\text { to relatively simple } \\
\text { repairs. }\end{array}$ \\
\hline $\begin{array}{l}\text { Office Practice } \\
\text { and Project } \\
\text { Management }\end{array}$ & $\begin{array}{l}\text { Bookkeeping, } \\
\text { placement }\end{array}$ & $\begin{array}{l}\text { full time } \\
\text { ongoing }\end{array}$ & 2 & $\begin{array}{l}\text { Training delivery by } \\
\text { CRDC staff }\end{array}$ \\
\hline $\begin{array}{l}\text { General } \\
\text { Building } \\
\text { Technology } \\
\text { (CAST) }\end{array}$ & $\begin{array}{l}\text { Construction } \\
\text { drawing, physics, } \\
\text { building } \\
\text { technology, math } \\
\text { and English }\end{array}$ & $\begin{array}{l}1 \text { day and } 2 \\
\text { evenings per } \\
\text { week for } 1 \\
\text { year }\end{array}$ & 2 & $\begin{array}{l}\text { Allows access to higher } \\
\text { level skills training and } \\
\text { building training } \\
\text { programs }\end{array}$ \\
\hline
\end{tabular}




\begin{tabular}{|c|c|c|c|c|}
\hline $\begin{array}{l}\text { Blueprint } \\
\text { (CRDC) }\end{array}$ & $\begin{array}{l}\text { Blueprint reading } \\
\text { and plan } \\
\text { interpretation }\end{array}$ & $\begin{array}{l}1 \text { evening per } \\
\text { week for } 12 \\
\text { weeks }\end{array}$ & 4 & \\
\hline $\begin{array}{l}\text { Driving } \\
\text { (individual } \\
\text { instruction) }\end{array}$ & Driving car & variable & 3 & Invaluable \\
\hline $\begin{array}{l}\text { Automechanics } \\
\text { (individual } \\
\text { instruction) }\end{array}$ & $\begin{array}{l}\text { Basic auto } \\
\text { mechanics and } \\
\text { car maintenance }\end{array}$ & $\begin{array}{l}\text { Saturday } \\
\text { afternoons for } \\
8 \text { weeks }\end{array}$ & 3 & $\begin{array}{l}\text { Aimed at cutting costs } \\
\text { of vehicle maintenance }\end{array}$ \\
\hline $\begin{array}{l}\text { Bookkeeping } \\
\text { and Secretarial } \\
\text { Skills } \\
\text { (Commercial } \\
\text { Business } \\
\text { College) }\end{array}$ & $\begin{array}{l}\text { Typing, } \\
\text { shorthand, } \\
\text { English }\end{array}$ & $\begin{array}{l}2 \text { evenings } \\
\text { per week for } \\
1 \text { year }\end{array}$ & 1 & \\
\hline $\begin{array}{l}\text { Drama } \\
\text { (Sistren- } \\
\text { Women's } \\
\text { Theatre Group) }\end{array}$ & $\begin{array}{l}\text { Explaining issues } \\
\text { affecting women } \\
\text { by using drama }\end{array}$ & 3 Saturdays & 2 & \\
\hline $\begin{array}{l}\text { First Aid } \\
\text { (Blue Cross) }\end{array}$ & General First Aid & $\begin{array}{l}2 \text { evenings } \\
\text { per week }\end{array}$ & 7 & \\
\hline On Site & $\begin{array}{l}\text { Skill upgrading in } \\
\text { trade areas where } \\
\text { women are working }\end{array}$ & $\begin{array}{l}\text { full time, } \\
\text { informal }\end{array}$ & 2 & $\begin{array}{l}\text { Quality very dependent } \\
\text { on individual foremen } \\
\text { and male gang leaders, } \\
\text { but probably the most } \\
\text { effective long-term form } \\
\text { of training }\end{array}$ \\
\hline $\begin{array}{l}\text { Improving the } \\
\text { Safety of } \\
\text { Wooden } \\
\text { Houses (CRDC) }\end{array}$ & $\begin{array}{l}\text { Carpentry, } \\
\text { masonry }\end{array}$ & $\begin{array}{l}1 \text { week } \\
\text { workshop }\end{array}$ & 2 & $\begin{array}{l}\text { This was an introductory } \\
\text { course. Long-term plans } \\
\text { call for using women as } \\
\text { instructors in outreach } \\
\text { programs. }\end{array}$ \\
\hline
\end{tabular}


Design: Ann Leonard

Typography: Village Type and Graphics

Photos: Ruth Mcleod

Printing: Graphic Impressions, Inc.

We invite your comments and your ideas for projects which might be included in future editions of SEEDS. If you would like additional copies of this issue or would like to be included on the SEEDS mailing list, please write to:

Ann Leonard, Editor

SEEDS

P.O. Box 3923

Grand Central Station

New York, New York 10163 U.S.A. 


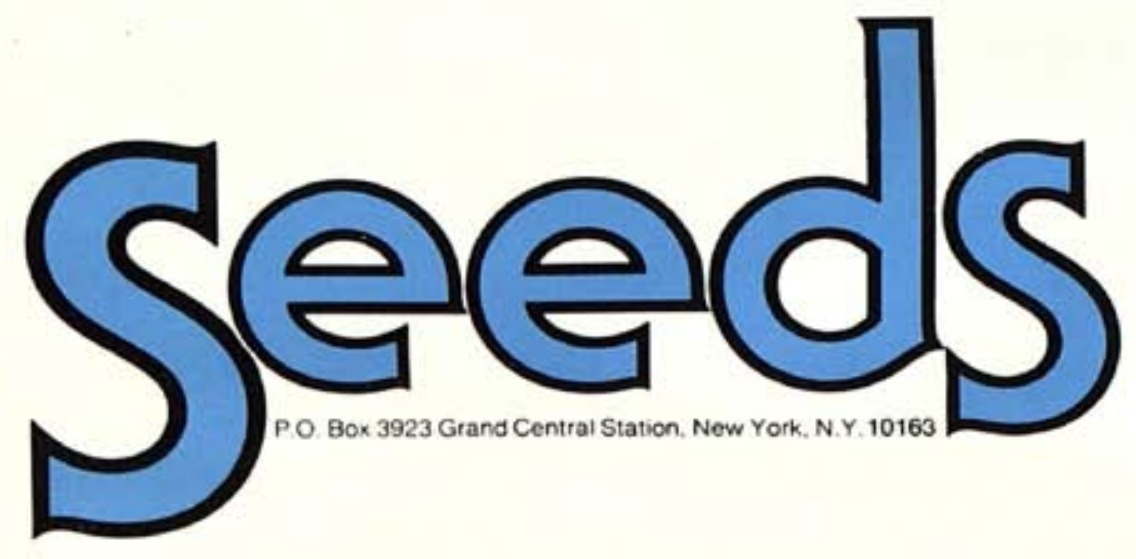

